\title{
FUNGI ON FEATHERS OF COMMON CLINICALLY HEALTHY BIRDS IN BELGRADE
}

\author{
B. Miljković ${ }^{1}$ Z. Pavlovski ${ }^{2}$, D. Jovičić ${ }^{3}$, O. Radanović $^{1}$, B. Kureljušić ${ }^{1}$ \\ ${ }^{1}$ Research Institute of Veterinary Medicine of Serbia, Belgrade, Republic of Serbia \\ ${ }^{2}$ Institute for Animal Husbandry, Autoput 16, P. Box 23, 11080, Belgrade-Zemun, Republic of Serbia \\ ${ }^{3}$ Faculty of Applied Ecology-Futura, University of Singidunum, Belgrade, Republic of Serbia \\ Corresponding author: biljamiljkovic55@gmail.com \\ Original scientific paper
}

Abstract: In the quarantines of the epyzootiological territory of Belgrade, feathers deriving from live and dead dehydrated exotic birds were samples. Birds were housed in closed disinfected bird shelter facilities with cages. Study was carried out in 4 quarantines of total 22, during 2010, and it included only 5 bird species, 3 birds of each species (Coracias cyanogaste, Acridothere tristis, $S$. canaria, Pycnonotus cafer and Tockus fasciatus). A total of 15 samples of feathers were analyzed. Samples were placed in the antibiotics solution, for 24 hours at room temperature, and subsequently cultivated on Sabouraud dextrose agar and Potato dextrose agar, in aerobic conditions in the darkness at the temperature of in $37^{\circ} \mathrm{C}$ duration of 5 days, and 3-4 weeks at $20 \pm 2{ }^{\circ} \mathrm{C}$ (Scopulariopsis spp.), and in aerobic conditions at room temperature of $20 \pm 2{ }^{\circ} \mathrm{C}$ for 5 days (Aspergillus spp., Penicillum spp. and Fusarium spp.) The presence of Scopulariopsis spp., Aspergillus spp., Penicillum spp. and Fusarium spp. was identified. The study showed that commonly healthy birds, as well as dead birds, which died mainly due to exhaustion and dehydration during transportation, can carry various fungi/moulds which contaminate the air, soil and water surrounding their habitats. Most of these birds are sold as closed domesticated pets which are clinically healthy birds, however, they can be important source of potentially pathogen causers which they carry on their body. This finding of fungal species on the body/feathers of birds are naturally suitable place for their transmission, and this also contributes to better understanding of the nature and occurrence of many wide spread diseases in transmiting mycoses.

Key words: fungi, birds feather, Belgrade quarantine 


\section{Introduction}

Most of imported birds, and especially parrots, kept in the house environment as pets, can potentially be dangerous in conditions of direct contact of humans with the feathers (Deshmukh et al., 2004). Bird's feathers are known carrier of microorganisms and especially of pathogen fungi which are capable to infect humans and animals (Camin et al., 1998; Anbu et al., 2004). In Serbia, mycological studies of the animal feed are done to prevent incidence of diseases and spreading of fungi (moulds) in the free space. Investigation of their prevalence was done in a study of the poultry feed by Krnjaja et al. (2008, 2010). Authors investigated in 2007 a total of 230 samples, and in 2008 total of 234 samples. Dominant presence of Fusarium $56.09 \%$ and $63.40 \%$, respectively was determined, as well as of Aspergillus $54.35 \%$ and $73.62 \%$. Also Rhizopus, Penicillium, Mucor and Alternaria were isolated.

Numerous cases of aspergillosis in humans were described (Baillot et al., 2001), in exotic birds (Michal and Orosz, 2000), and intensively reared poultry (Ivetić et al., 2003), in chickens after artificial infection (Ivetić et al., 1999), whereas (Spalević et al., 2010) described its incidence in broiler chickens in hatching stations, and (Kureljušić et al., 2010) contributed to diagnostics of aspergilosis.

The following authors report on non-identified white-grey-brown fungi on bird's feathers and alterations on skin of broiler parent hens in Serbia (Miljković et al., 2006, 2009), Scopulariopsis brevicaulis, was described for the first time as Penicillium brevicaulis Sacc. (Bainer 1907) but anamorph-teleomorph connections with Microascus brevicaulis sp. nov. the teleomorph of Scopulariopsis brevicaulis, and heterothallism in the Microascaceae by Abbott et al. (1998) and Abbot and Lynne, (2001) and its dimorphism was described by (Paula et al., 1987).

Finding of Aspegillus niger, Fusarium spp. Trichophyton spp. Mucor spp., Penicillium spp., Chrysosporium spp. and Scopulariopsis brevicaulis in samples from hoofs horn of 8 investigated horses in Wien was reported by (Apprich et al., 2009).

Scopulariopsis brevicaulis was proven as cause of lack of hair cover on the skin of two goats and it was described by (Ozturk et al., 2009) in turkey.

In a study of the presence of fungal species in poultry feed in Egypt, Scopulariopsis brevicaulis was detected in wheat, soy bean and fish meal, as well as Mucor spp., Aspergillus spp., Penicillium spp., Rhizopus spp., Fusarium spp. and other species (Moharram et al., 1987).

Animal diseases caused by mycological agents have not been described in Serbia as much as diseases present in the environment, on plants, in recreational waters (Matavulj et al., 2005). Authors Muntañola- Cvetković and Ristanović $(1977,1980)$, are considered as initiators of the research of potential micro fungi in 
the waters of South Adriatic, as a connection between men and waste present on the sea coast. Some authors study indigenous micro fungi of lakes such as Vlasina lake (Vukojević et al., 1997), and Sava lake (Ljaljević et al., 2000). In all reports obtained from mentioned studies, presence of Aspergillus, Penicillium, Alternaria, Trichoderma, Mucor and Rhizopus species, Cladosporium spp. was confirmed as well as other potential allergens, and also fungi which accompany infections of immunedeficient persons, are noticed.

In addition to mentioned data referring to their presence, our study as a pilot experiment can point to the introduction of fungi (moulds) into our environment through import of otherwise healthy birds. Of course, this finding explains their natural introduction through bird migration since they know no borders.

\section{Materials and Methods}

Quarantines for imported birds were located within the Belgrade epyzootiological territory. Total number of birds clinically observed in this study housed in 4 quarantines was 2260. Birds were commonly healthy, only in 2 quarantine cases deaths of birds during transport were reported, caused by dehydration during summer months. Larger birds suffered more during transport. Study was conducted on following bird species: Coracias cyanogaster (Bluebellied roller), order Coraciiformes; Acridotheres tristis (Common mynaor indian myna) order Passeriformes; Tockus fasciatus (African pied hornbill) order Coraciiformes; Familiy Fringillidae ( $S$. canaria) genus Serinus, order Passeriformes; Pycnonotus cafer (Red-vented bulbul) order Passeriformes.

Investigation included healthy birds and birds which died of exhaustion and lack of water. Feathers were taken, using medical gloves and aseptic tools from 3 birds per species. Four subsamples from each bird consisting of at least five feathers were plucked aseptically and carefully from the neck area, outside and inside of the wings and around cloaca. These subsamples were mix to prepare one composite sample per bird. Collective feather samples per bird were marked according to the species and packaged into pvc bags with zipper, and transported in a mobile refrigerator and stored before analysis at $+4^{\circ} \mathrm{C}$.

Isolation of fungal species was done by cultivation of feather samples kept in the antibiotic solution for 24 hours (penicillin $10.000 \mathrm{U} \mathrm{ml}^{-1}$, streptomycin 10 $\mathrm{mg} \mathrm{ml}^{-1}$, gentamicin sulphate $50 \mathrm{mg} \mathrm{ml}^{-1}$ ) and subsequently directly cultivated on selective medium for fungi - Sabouraud dextrose agar, and cultivated aerobic at $20 \pm 2$ for 5 days. More white colonies of Aspergillus spp. were spotted already after 18 hours, and after growth period of 48 hours it could be distinguished macroscopically from colonies of Penicillium spp. Identification was based on 
description of Mihajlović (1983), and Alvin and Michael, (1991) as well as identification of Fusarium spp. and Penicillium spp.

In order to obtain better macro and micro characteristics of Fusarium spp., potato dextrose agar (Nash and Michelle., 1991) was used.

Isolation of Scopulariopsis spp. was done on same mediums for duration of 5 days on $37^{\circ} \mathrm{C}$ in absolute darkness, and continuous subculturing (5 to 5 days) was realized on potato-dextrose agar at $20 \pm 2{ }^{\circ} \mathrm{C}$ for 3-4 weeks (Paula et al., 1987). Obtained culture was microscopically and macroscopically compared to identified and maintained culture of Scopulariopsis brevicaulis isolate number 03-224 of 2009 in Reference Mycologi laboratory, Bristol UK. Microscopic characteristics were obtained by preparation of the native preparation and staining by using laktophenol blue. Species Scopulariopsis brevicaulis has macroscopic characteristics of colonies which is granular surface to powder texture. From the front, colour is white at the beginning and later it turns grey or light brown. Microscopically septa hyphae, conidiophores, annelids and conidia can be seen. Conidiophores are either simple or they branch. Annelids are solitary, in bunches or in pennicilus form: they cylindrical and slightly thickened. Conidia are single cell, round or piriform, smooth, sometimes also coarse, or even barbed surface (Muntañola-Cvetković 1990; Abbott et al., 1998, 2001).

\section{Results and Discussion}

Birds in migration know no borders and they carry on their feathers everything present in their environment, either on land or in air. Cafarchia et al. (2006) stated that domestic and wild birds are known carriers of human pathogen fungi. In their research of the presence of yeast in cloacae, included 1726 birds of which $421(24.39 \%)$ were migrating from the territory of Romania, Hungary and Bulgaria.

Our finding showing presence of $80 \%$ of fungal species in 15 feather samples from 5 bird species is in accordance to study performed in Kingdom of Bahrain (Qaher et al., 2009), on 10 birds species where they reported that $69.77 \%$ of samples were positive in regard to presence of fungi. Also, they determined the presence of keratinophylic fungi, as well as presence of Scopulariopsis spp. in pigeon, parrot, quail, ducks and chicken. Our results are presented in Table 1. 
Table 1. Isolated fungal genera from feather samples at investigated bird species

\begin{tabular}{|c|c|c|c|c|c|c|}
\hline \multirow[b]{2}{*}{ Bird species } & \multicolumn{4}{|c|}{ Fungal genera } & \multirow[b]{2}{*}{$\begin{array}{l}\text { Positive } \\
\text { samples }\end{array}$} & \multirow[b]{2}{*}{$\begin{array}{l}\text { Negative } \\
\text { samples }\end{array}$} \\
\hline & Aspegrillus & Fusarium & Penicillium & Scopulariopsis & & \\
\hline C. cyanogaster & + & + & - & - & 2 & 1 \\
\hline A. tristis & - & - & + & - & 3 & - \\
\hline T. fasciatus & - & - & + & + & 3 & - \\
\hline Fringillidae & + & - & + & - & 3 & - \\
\hline P. cafer & - & + & - & - & 1 & 2 \\
\hline $\begin{array}{l}\text { Number (\%) of } \\
\text { isolates (samples) }\end{array}$ & $2(25 \%)$ & $2(25 \%)$ & $3(37.5 \%)$ & $1(12.5 \%)$ & $12(80 \%)$ & $3(20 \%)$ \\
\hline
\end{tabular}

Obtained results indicate that in the environment where birds are kept closed in cages, there may be dust particles in the air, potential carriers of sporogenic pathogens. According to accompanying documentation kept in individual quarantines, it is obvious that certain birds were artificially reared on farms. Birds are transported in cages where they are provided food and water, while travelling from Tanzania, Guinea and Arab Emirates. Obtained finding of fungi is not unusual since feathers can carry all of these agents. Mbata (2009) determined Microsporium gallinae, Microsporium gypseum, Trichophyton mentagraphytes, Candida albicans, Fusarium spp., Scopulariopsis spp., Alternaria alternata, Aspergilus flavus on few wing feathers of chickens reared in warm regions, which are called „featherless broilers“, and had clinical skin superficial mycoses.

Camin et al. (1998) report of the presence of Scopulariopsis brevicaulis and other keratinophylic fungi on sparrow feathers (Sturnus vulgaris), their movement radius is associated with urban and rural parts of France.

On waste sites - land fills surrounding 10 poultry farms where chicken are reared on the waste surrounding farms in the region of Tami Nandu in India, research was carried out on remains of the feathers on presence of keratinolytic fungi. In the soil, the most frequent were Chrysosporium keratinophilum $73 \%$, Microsporium gypseum 64\% and other fungi, but Scopulariopsis brevicaulis was also isolated and is presence of 5.64\% determined (Anbu et al., 2004).

In addition to soil contamination, they also are transmitted through water, air but also mechanically through ticks.

Yoder et al. (2005) reported of American dog tick, Dermacentor variabilis which was proven to be mechanical vector of yeast (mould) Scopulariopsis brevicaulis. This tick also is transmitter of Rocky mountain spotted fever and within its biological control in the nature Scopulariopsis brevicaulis could not be included. Therefore, the same authors, after extended laboratory investigation, have succeeded in proving endosimbiotic conidial fungus Scopulariopsis brevicaulis 
which has role to protect the tick from other species of entomopathogenic fungus Metarhizium anisopliae. (Yoder et al., 2008).

Cages in which birds are housed during the quarantine are presented in (Figure 1a,b,c,d) and pictures of birds (Figure 1e,f,g,h,i) included in the quarantine research were taken from $\underline{w w w \text {. wikipedia.com }}$
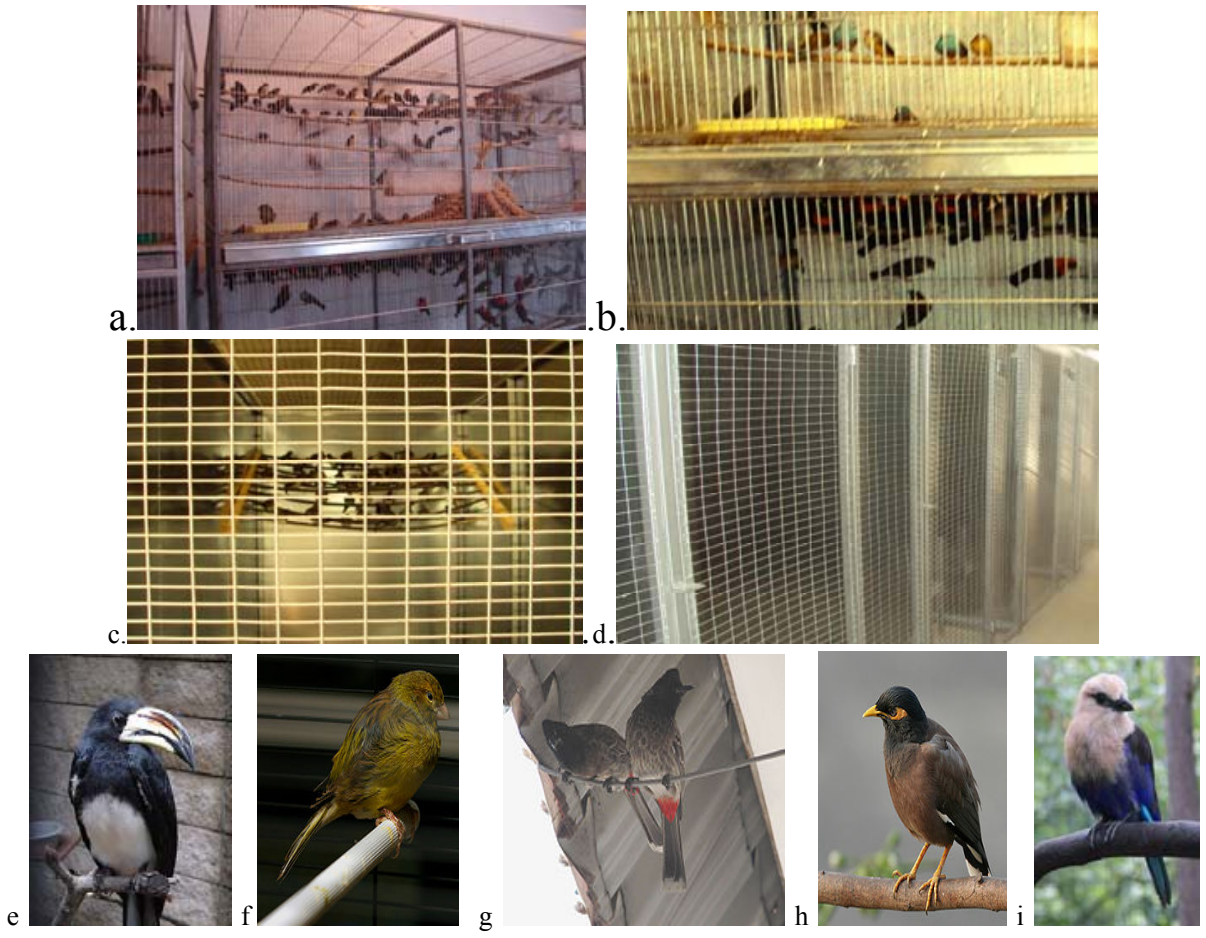

Figure 1. Cages used for housing of birds (a,b,c,i d); Tockus fasciatus (e) S. canaria (f) Pycnonotus cafer (g) Acridotheres tristis (h) Coracias cyanogaste.(i)

During quarantine, air is disinfected as prevention and food for birds or seeds used in their nutrition are treated with fungicide preparations preventing the development of sporogenic moulds. Of course, it is necessary to exclude the presence of eco-parasites as potential mechanical carriers of fungi.

\section{Conclusion}

Such researches expend the knowledge of distribution of ubiquitous fungi present so far usually only in and on the soil. 
At the same time, such studies help identify the natural habitats of the pathogenic fungi and contribute to our understanding of the epidemiology of infections caused by them.

\title{
Acknowledgment
}

Research was financed by the Ministry of Science and Technological Development, Republic of Serbia, project TR 31033.

\section{Gljive na perju obično klinički zdravih ptica u Beogradu}

\author{
B. Miljković, Z. Pavlovski, D. Jovičić, O. Radanović, B. Kureljušić
}

\section{Rezime}

U karantinima na epizootiološkom području Beograd, uzorkovano je perje od živih i perje od uginulih egzotičnih ptica. Ptice su bile smeštene dezinfikovane $u$ zatvorene objekte sa kavezima za prihvat ptica. Ukupno je obuhvaćeno 4 karantina od ukupno 22 tokom 2010. godine. Pregled je obuhvatio 5 vrsta ptica a od svake vrste uzorkovane su po 3 ptice (Coracias cyanogaste, Acridothere tristis, S. canaria, Pycnonotus cafer $i$ Tockus fasciatus). Ukupno je ispitano 15 uzoraka perja. Uzorci su postavljeni u rastvor antibiotika, držani 24 sata na sobnoj temperaturi a potom kultivisani na Sabouraud dekstroznom agaru i na krompir dekstroznom agaru, aerobeno u mraku na $37^{\circ} \mathrm{C} 5$ dana, a zatim 3-4 nedelje na $20 \pm 2^{\circ} \mathrm{C}$, (Scopulariopsis spp.), i samo aerobno na sobnoj temperaturi od $20 \pm 2^{\circ} \mathrm{C} 5$ dana (Aspergillus spp., Penicillum spp., i Fusarium spp.). Identifikovano je prisustvo Scopulariopsis spp., Aspergillus spp., Penicillum spp. i Fusarium spp.

Ispitivanje ukazuje da obično klinički zdrave kao i uginule ptice, najčešće uginule zbog iscrpljenosti i dehidratacije $u$ transportu, mogu da donesu na sebi raznovrsne gljive/plesni kojima se kontaminira vazduh, zemlja i voda u okolini u kome borave. Mikološki je ispitano perje uginulih i perje uzorkovano od živih egzotičnih ptica u karantinu, na epizootiološkom području Beograda.

Većina ovih ptica se prodaju kao zatvoreni kućni ljubimci koji su klinički zdrave ptice ali mogu da budu važan izvor potencijalno patogenih uzročnika kod prenošenja mikoza. Ovaj nalaz gljiva na telu/perju ptica otkriva prirodno mesto za njihovo prenošenje, i takođe doprinosi boljem razumevanju prirode i nastanka veoma rasprostranjenih bolesti koje su prouzrokovane navedenim uzročnicima mikoza. 


\section{References}

ABBOTT S.P, LYNNE S. (2001): Heterothallisam in the Microascaceae demonstrated by three species in the Scopulariopsis brevicaulis series. Mycologia, 92, 6, 1211-1229.

ABBOTT S.P., SINGER L., CURRAH R.S. (1998): Microascus brevicaulis sp. nov., the teleomorph of Scopulariopsis brevicaulis, supports placement of Scopulariopsis with Microascaceae. Mycologia, 90, 279-302.

ANBU P., HILDA A., GOPINATH S.C.B. (2004): Keratinophlic fungy of poultry farm and feather dumping soil in Tamil Nadu, India. Mycopathologia, 158, 303-309.

APPRICH V., ASPERGSER J., ROSENGARTEN R., STANEK C. (2009): Scanning electron microscopy and fungal culture of hoof horn from horses suffering from onychomycosis. Veterinary Dermatology, 21, 335-340.

ALVIN L.R., MICHAEL J. (1991): Oportunistic hyaline Hyphomycetes. In: BALOW A., WILLIAM J., HAUSLER J.R., KENETH L., HERRMAN H.D., ISENBERG H., SHADOMY H.J. (eds.), Manual of clinical microbiology, Chapter 63, 659-673. Fifth Edition, American Society for Microbiology, Washington D.C.

BAILLOT D., MANNONE LB., COUAILLIER J.F. (2001): Role of early diagnosis and aggressive surgery in the management of ivasive pulmonary aspergillosis in neutropenic patients. Clinical Microbiology and Infection, 7, Supplement 2, 54-61.

BAINER G. (1907): Mycotheque del' Ecole de Pharmacie- XIV. Scopulariopsis (Penicillium pro parte), genre nouveau de Mucedinees. Bull. Soc. Mycolo. France, 23, 98-105.

CAFARCHIA C., CAMARDA A., ROMITO D., CAMPOLO M., QUAGLIA N.C., TULLIO D., OTRANTO D. (2006): Occurrence of yeasts in cloacae of migratory birds. Mycopathologia, 161, 229-234

CAMIN A.M., CHABASSE D., GUIGUEN C. (1998): Keratinophilic fungi associated with starlings (Sturnus vulgaris) in Brittany, France. Mycopathologia, 143, 9-12.

DESHMUKH S.H. (2004): Isolation of dermatophytes and other keratinophilic fungi from the vicinity of salt pan soil of Mumbai, India. Mycopathologia, 157, 265-267.

IVETIĆ V., VALTER D., PAVLOVIĆ I., MILJKOVIĆ B., MASLIĆ STRIŽAK D., ILIĆ Ž., SAVIĆ B., STANOJEVIĆ S., SPALEVIĆ LJ. (2003): Atlas bolesti živine, Naučni institut za veterinarstvo Srbije, Beograd.

IVETIĆ V., MILJKOVIĆ B., MASLIĆ-STRIŽAK D., VALTER D. (1999): Mikromorfološke promene na opnama embrioniranih jaja kod veštaćke infekcije sa Aspergillus fumigatus. Program II jugoslovenskog simpozijuma "Nauka u živinarstvu", Vrnjačka Banja, Nauka u živinarstvu, 4, 1-2, 41-45. 
KRNJAJA V., STOJANOVIĆ LJ., CMILJANIĆ R., TRENKOVSKI S., TOMAŠEVIĆ D. (2008): The presence of potentially toxigenic fungi in poultry feed. Biotehnology in Animal Husbandry, 24, 5-6, 87-93.

KRNJAJA V., STOJANOVIĆ LJ., TRENKOVSKI S., BIJELIĆ Z., TOMAŠEVIĆ D. (2010): The frequency of pathogenic fungi genera in poultry feed. Journal of Food, Agriculture \& Environment, 8, 3-4, 589-591.

KURELJUŠIĆ B., SAVIĆ B., PRODANOVIĆ R., ĐEKIĆ J., ADAMOV V., JAKIĆ -DIMIĆ D., MILJKOVIĆ B., RADOVANOVIĆ O., IVETIĆ V. (2010): Primena različitih histohemijskih metoda u dijagnostici aspergiloze mozga kod ćuraka. Zbornik kratkih sadržaja sa Savetovanja veterinara, Zlatibor, 130.

LJALJEVIĆ M. (2000): Terestrichne mikromicete izolovane iz vode Savskog jezera, Magistarski rad, Biološki fakultet, Univerzitet u Beogradu, 1-102.

MATAVULJ N.M.., VULIKIĆ N., GOJKOVIČ I., KARAMAN A.M. (2005): Conditionally pathogenic fungi in recreational waters. Zbornik matice srpske za prirodne nauke Novi Sad, 109, 149-160.

MBATA T.I (2009): Dermatophytes and other skin mycoses found in featherless broiler toe webs. Internet Journal of Dermatology, 7, 22-7.

MICHAEL P.J., OROSZ E.S. (2000): The diagnosis of aspergillosis in birds. Seminar in Avian and Exotic Pet.Medicine, 9, 2, 52-58.

MILJKOVIC B., MIĆIĆ M., VUKOJEVIĆ J., GRBIĆ LJALJEVIĆ M. (2006): Indukcija bolesti kod miševa neidentifikovanim agensom prisutnim u krvi obolelih kokica. Zbornik kratkih sadržaja VIII Epizootiološki dani, Vrdnik, 101-102.

MILJKOVIC B., RADOVANOVIĆ O., PAVLOVSKI Z. (2009): Citološka ispitivanja u dijagnostici nekih patoloških agenasa u ptica. 8. Kongres veterinara Srbije. Zbornik kratkih sadržaja, (CD ) Veterinarske Medicine, Život i zdravlje.

MOHARRAM A.M., BAGY M.M.K., ABDEL-MALLEK A.A.Y. (1987): Saprophytic fungi isolated from animal and bird pens. Egypt J. Basic Microbiolo., 27, 7, 361-367.

MUTAÑOLA- CVETKOVIĆ M., RISTANOVIĆ B. (1977): Rare species of microfungi isolated from South Adriatic Sea Waters. Mikrobiologija, 14, 1, 59-68.

MUTAÑOLA-CVETKOVIĆ M., RISTANOVIĆ B. (1980): A mycological survey of South Adriatic Sea. J. Exp. Mar. Biol. Ecol., 43, 193-206.

MUTAÑOLA- CVETKOVIĆ M. (1990): Opsta mikologija, NIRO "Književne novine" Beograd.

MIHAJLOVIĆ B. (1983): Prirucnik za identifikaciju bakterija kvasaca i plesni. Poglavlje metode za izolovanje identifikaciju i važnih vrsta plesni. Savez veterinara i veterinarskih tehnicara. Odbor za izdavacku delatnost Jugoslavije. NASH P., MICHELLE M.K. (1991): In: BALOW A., WILLIAM J., HAUSLER J.R., KENETH L., HERRMAN H.D., ISENBERG H., SHADOMY H.J. (eds.), Manual of clinical microbiology, Chapter 121, Culture Media, 1226-1288. Fifth Edition, American Society for Microbiology, Washington D.C. 
OZTURK D., RAMAZAN A., TURUTOGLU H. (2009): Superficial skin infection with Scopulariopsis brevicaulis in two goats. A Case Report. Bull Vet Inst Pulawy, 53, 361-363.

PAULA C.R., PURCHIO A., GAMBEL W., CORREA B. (1987): Dimorphism of Scopulariopsis bevicaulis: Morphogenesis of the mould to yeast phase. Mycopathologia, 100, 69-74.

QAHER M., NARDONI S., MANCIANTI F. (2009): Keratinophilic fungi on feathers of common clinically healthy birds in Bahrain. Mycoses, 54, 71-77.

SPALEVIĆ LJ., MASLIĆ-STRIŽAK D., ILIĆ Ž., MILJKOVIĆ B. (2010): Značaj nekih bioloških agenasa sa posebnim osvrtom na Aspegillus fumigatus na rezultate inkubacije jaja. Zbornik kratkih saržaja XII epizootiološki dani Oplenac-Topola, 124-125.

VUKOJEVIĆ J., FRANIĆ-MIHAILOVIĆ F., DULETIĆ-LAUŠEVIĆ (1997): Soil micromycetes in the aquatic ecosystem of Vlasinsko lake and its tributaries. Mycologia Helvetica, 9, 1, 121-136.

YODER A,. JOSHUA. B.J., BENOIT E., RELLINGER J., TELFORD S.R. (2005): Failure of ticks to transmit Scopulariopsis brevicaulis (Deuteromycota), a common filamentous fungal commensal of ticks. J. Med. Entomol., 42, 3, 383-387.

YODER A., JOSHUA B.J., BENOIT E., DENLINGER D.L., JUSTIN L., LAWRENCE T., ZETTLER W. (2008): An endosymbiotic conidila fungus, Scopulariopsis brevicaulis, protects the American dog tick, Dermacentor variabilis, from desiccation imposed by an entomopathogenic fungus. Journal of Invertebrate Pathology, 97, 119-127. 